Белянская Т.Э.,

\title{
Психолого-педагогические условия развития коммуникативных компетенций
} студентов

${ }^{1}$ Воронежский Государственный Лесотехнический Университет

${ }^{2}$ Воронежский Государственный Педагогический Университет (Россия, Воронеж)

doi: $10.18411 / 1 j-08-2021-64$

\section{Аннотация}

В статье рассматривается процесс создания психолого-педагогических условий для успешной реализации развития коммуникативных компетенций студентов. Выявляются различия понятий «компетенция» и «компетентность». Характеризуется компетентностный подход, как наиболее эффективная среда для реализации цели развития компетенций.

Ключевые слова: психолого-педагогические условия, компетенции, компетентность, компетентностный подход в образовании, педагогический процесс.

\section{Abstract}

The article examines the process of creating psychological and pedagogical conditions for the successful implementation of the development of students' communicative competencies. The differences between the concepts of "competence" and "competence" are revealed. The competence-based approach is characterized as the most effective basis for realizing the goal of developing competencies.

Keywords: psychological and pedagogical conditions, competencies, competence, competence-based approach in education, pedagogical process.

Современное российское образование находится в стадии модернизации и опирается в своем развитии на мировую образовательную практику. Ключевыми понятиями в данной парадигме являются «компетенции». Развитие компетенций в образовании наиболее эффективно осуществимо при реализации компетентностного подхода. Цель данного подхода - объединение знаний, навыков и мыслительной деятельности, что дает результат повышения качества образования и формирование личности, обладающей профессиональными и человеческими качествами, ориентированной на достижение высоких целей в самореализации [3].

Высшая школа уделяет большое внимание развитию и формированию компетенций студентов - будущих профессионалов своего дела. Для этого необходимо создание определенных психолого-педагогических условий. Словарь Ожегова трактует понятие «условие», как обстоятельство, от которого зависит что-либо, и, с другой стороны, как обстановку, в которой что-либо осуществляется [9]. Педагогические условия представляют собой качественную характеристику основных факторов, процессов и явлений образовательной среды, отражающую основные требования к организации деятельности, совокупность объективных возможностей, обстоятельств педагогического процесса, целенаправленно создаваемых и реализуемых в образовательной среде, и обеспечивающих решение поставленной педагогической задачи [8], [11]. Психолого-педагогические условия строятся и развиваются при проведении педагогического процесса - особой формы взаимодействия педагогов и учащихся, ведущей к личностному росту. Организационные и методологические особенности педагогического процесса могут варьироваться и напрямую влиять на ожидаемые результаты [1], [10].

Анализ научных трудов, посвященных данной теме дает нам повод выделить группы психолого-педагогических условий: 
1. познавательная - включает содержательный компонент образования, является основой педагогического процесса;

2. методическая - способы организации образовательной деятельности, подбор научной литературы и разработка инновационных методов взаимодействия при педагогическом процессе;

3. индивидуально-личностная - качества субъектов образования, их поведенческие модели, психологическая составляющая образовательного процесса [2], [8], [12].

Для успешного развития компетентности личности создаются психологопедагогические условия, использующие компетентностный подход обучения студентов. Данный подход позволяет эффективно развивать компентенции и реализует такие цели образования, как обучаемость, самоопределение, самоактуализация, социализация и развитие индивидуальности [3].

Ориентация образовательного процесса на компетентностный подход обусловлен глобализацией мировой экономики, общеевропейской и мировой интеграцией образования, введение терминов с широким понятийным содержанием [5].

Компетентностный подход предусматривает особую роль преподавателя сопровождающего при образовательном процессе, то есть ставит своей целью развитие компетенций при самостоятельной и целенаправленной деятельности студента, усвоения им новых социальных ролей и обретение новых социальных контактов [13]. Основной упор делается на развитие креативности и самостоятельности мышления студента, дифференцированный подход к каждому студенту, использование инновационных методов обучения, которые обеспечивают развитие коммуникативных качеств, создают атмосферу взаимопомощи и взаимовыручки. Компетентностный подход в образовании позволяет увидеть взаимосвязь теории с реальным состоянием в профессиональной сфере будущего выпускника [6]. Э.Ф. Зеер отмечает, что при осуществлении компетентностного подхода применимы когнитивно-ориентированные методы преподавания, а именно: дискуссии на проблемные вопросы, ролевые игры, кейс-методы, проектные работы, тренинги [3], [4]. Компетенции студентов - это совокупность социальных и профессиональных характеристик, реализация различных социальных ролей. Компетентностный подход предполагает творческое развитие мышления студента, адаптацию в меняющихся условиях существования, в умении находить и использовать информацию. Развитие компетенций в русле компетентностного подхода связано с содержательной стороной обучения, структурой обучающих программ, межпредметностью, сочетанием инновационных вариантов с традициями преподавания, незыблемостью, воспитанием социальных навыков взаимодействия и общения, обучению профессиональным навыкам, развитием целеустремленности, самостоятельности, активности студентов, их конструктивного взаимодействия с педагогами в рамках обучения. Компетенции личности формируются с учетом закономерности деятельностных и мыслительных процессов, направленных на систематизацию знаний [7]. Следует учитывать применение последовательности методов и приемов образовательной деятельности, которые должны привести к планомерному развитию психологических характеристик компетенций: познавательных, мыслительных, деятельностных, поведенческих, мотивационных. Для эффективного формирования блока компетенций подходят занятия студентов, основанные на самостоятельном подборе информации, анализе полученных знаний, умении кооперироваться для разработки проектных работ. Наиболее конструктивными для формирования коммуникативных компетенций являются методы: «Мозговой штурм», «Свободное письмо», «Ролевая игра», «Инсерт», «Синквейн», «Зигзаг». В ходе применения данных методов активизируется взаимодействие студентов, совершенствуются этикетно-речевые, дискуссионностилистические, риторико-прагматические компоненты коммуникативной 
компетентности. Реализация компетентностного подхода невозможна без внедрения приемов мнемической деятельности, витагенного образования, дискуссионных занятий с постановкой проблемного вопроса, эмоционально воздействующих тренингов.

ФГОС 3++ гласит о потребности формирования коммуникативных компетенций у студентов различных направлений подготовки. Вот некоторые из них: УК-3 способен осуществлять социальное взаимодействие и реализовывать свою роль в команде; УК-3.1 определяет цели и задачи команды в целом, а также каждого члена команды. Имеет опыт участия в командной работе. Понимает собственную роль в команде; УК-3.3 понимает эффективность использования стратегии сотрудничества для достижения поставленной цели; УК-3.5 эффективно осуществляет взаимодействие с другими членами команды: участвует в обмене информацией, знаниями, опытом и т.д.; УК-4 способен осуществлять деловую коммуникацию в устной и письменной формах на государственном языке Российской Федерации и иностранном(ых) языке(ax); УК-4.2 использует информационно-коммуникационные технологии при поиске необходимой информации в процессе решения стандартных коммуникативных задач на государственном языке Российской Федерации и иностранном(ых) языке(ax); УК-4.3 демонстрирует умение осуществлять деловую коммуникацию в устной и письменной формах, используя методы и навыки делового общения; УК-9.1 обладает представлениями о принципах недискриминационного взаимодействия при коммуникации в различных сферах жизнедеятельности, с учетом социальнопсихологических особенностей лиц с ограниченными возможностями здоровья [14].

Как мы видим, коммуникативные компетенции прописаны официальным документом РФ и являются необходимыми для подготовки профессионалов высокого уровня. Коммуникативные компетенции должны быть адаптивными к разным условиям, оставлять возможность для их дальнейшего развития и совершенствования, понятными для тех, кому они адресованы. Реализация компетентностного подхода позволит ВУЗам выпускать высококвалифицированных специалистов своего профиля подготовки, чувствующего себя уверенно на рынке труда, профессионалов готовых к решению нестандартных ситуаций, личности стремящейся к постоянному развитию и поиску новых задач. Создание образовательной среды включает в себя разработку методических подходов к обучению и технологий диагностики и оценки компетенций студентов, начиная с преподавателя и заканчивая уровнем факультетских достижений. Формирование компетенций социально и профессионально-мобильной личности - это результат междисциплинарных действий и организации образовательных методов, учебно-воспитательной работы.

$$
* * *
$$

1. Беспалько В.П. Слагаемые педагогической технологии / В.П. Беспалько. М.: Педагогика, 1989. $191 \mathrm{c}$.

2. Ганин Е.А. Педагогические условия использования современных информационных и коммуникационных технологий для самообразования будущих учителей (Электронный ресурс) / Е.А. Ганин. - http://ito.edu.ru/2003/VII/VII-0-1673.html

3. Зеер Э.Ф Компетентностный подход к образованию [Электронный ресурс] / Э.Ф. Зеер. - Режим доступа: $\mathrm{http}: / /$ www.urorao.ru/konf2005.php

4. Зеер Э.Ф. Модернизация профессионального образования: компетентностный подход / Э.Ф. Зеер // Образование и наука. 2004. № 3 (27).

5. Зимняя И.А. Ключевые компетентности как результативно-целевая основа компетентностного подхода в образовании: авторская версия / И.А Зимняя. - М.: Исследовательский центр проблем качества подготовки специалистов, 2004. - С. 8-10.

6. Исаев В.А. Образование взрослых: компетентностный подход: монография / В.А. Исаев. Великий Новгород, 2005.

7. Карнеев Р.К., Краснопольская Н.С., Минава С.С. Социальная компетентность в структуре социального и эмоционального интеллекта психологов образования: Монография. Брянск: Изд-во «Курсив», 2011. 
8. Мошкин В.Н. Педагогические условия воспитания культуры безопасности (Электронный ресурс)/ B.Н. Мошкин. - http://www.oim.ru/reader.asp

9. Ожегов С.И. Словарь русского языка / С.И. Ожегов // Под ред. Н.Ю. Шведовой. М.: Рус. яз., 1981. $-2314 \mathrm{c}$.

10. Столяренко Л.Д., Основы психологии / Л.Д. Столяренко. Ростов н/Д, Изд-во Феникс, 2009. - 672 с.

11. Степченко Т.А., Ретивых М.В., Технологии формирования профессиональной компетентности обучающихся в организациях профессионального образования. Брянск: РИО БГУ: Материалы международной научно-практической конференции, 2013.

12. Тулегенова А.Г. Некоторые психолого-педагогические условия оптимизации учебновоспитательного процесса (Электронный ресурс) / А.Г. Тулегенова. http://www.crimea.edu/tnu/magazine/scientist/edition3/n03019.html

13. Хуторский А.В. Ключевые компетенции: технология конструирования // Народное образование. 2003. - № 5, c. 55-61.

14. ФГОС $3++$ http://fgosvo.ru/fgosvo/151/150/24

Большакова В.А.

Профилактика и коррекция синдрома выгорания

«Калужский государственный университет имени К.Э. Циолковского»

(Россия, Калуга)

doi: $10.18411 / \mathrm{j}-08-2021-65$

\section{Аннотация}

Статья посвящена изучению причин появления синдрома выгорания. На основании изученных данных показано то, что основной причиной проявления синдрома выгорания является переутомление и развитие хронического профессионального стресса. Предполагается, что разработка оптимального и индивидуального режима отдыха и профилактики положительно скажется и на психическом, и физическом самочувствии человека, снизит возможность появления переутомления и выгорания.

Ключевые слова: профессиональное выгорание, эмоциональное выгорание, переутомление, профессиональный стресс, нагрузка, профилактика.

\section{Abstract}

The article is devoted to the study of the causes of burnout syndrome. Based on the data studied, the author shows that the main cause of the manifestation of burnout syndrome is overwork and the development of chronic occupational stress. The author believes that the development of an optimal and individual regimen of rest and prophylaxis will have a positive effect on the mental and physical well-being of a person, reduce the possibility of overwork and burnout.

Keywords: professional burnout, emotional burnout, overwork, professional stress, load, prevention.

Впервые интерес к эмоциональному выгоранию возник в начале 1980-х годов, но исследования носили только теоретический характер. В настоящее время нет единой точки зрения на определение термина «выгорание». Наиболее распространенное определение предложил Р. Смит, который считает, что эмоциональное выгорание - это реакция на хронический стресс, включающий физический, поведенческий и когнитивный компоненты.

Основная причина выгорания - конфликт ресурсов и требований к человеку, в результате чего возникает умственное переутомление, нарушается состояние психического равновесия. Симптомы выгорания могут появиться без каких-либо патологических проблем. Также стоит отметить, что выгорание - это реакция не на острый стресс, а на хронический.

Проблеме «выгорания» уделяется гораздо больше внимания, чем проблеме переутомления. «Выгорание» - это сложная психофизиологическая реакция, вызванная частыми усилиями, иногда чрезмерными и, следовательно, неэффективными. Если 